\title{
Research on the Development of Modern Apprenticeship in Higher Vocational Colleges
}

\author{
Na Li, Xia Zhao, Chengjie Luan, Zhaojun Ren, Xiaolin Zhang \\ Binzhou Polytechnic, Binzhou, 256603 China \\ 411245815@qq.com
}

Keywords: modern apprenticeship, project cost, existing problems, measures and suggestions

\begin{abstract}
The modern apprenticeship system is a research hotspot in the process of education and teaching reform in China's Higher Vocational Colleges in recent years. It is an effective way to alleviate the contradiction between the supply and demand of the labor force in the present society. Taking the engineering cost major as an example, this paper explores the problems faced by the modern apprenticeship in the implementation process and puts forward corresponding measures and suggestions for these problems.
\end{abstract}

\section{Introduction}

In recent years, along with the vigorous development of our national economy and the continuous promotion of scientific and technological strength, on the one hand, the demand for talents is increasing, and many enterprises are facing the problem of "labor shortage". On the other hand, higher vocational colleges must constantly improve and improve their teaching mode so as to adapt to the new needs of the society to solve the problem of "difficult employment" for students. In 2010, the outline of the $<$ National medium and long term education reform and development plan (2010-2020) > explicitly proposed that "the development of vocational education is the key link to alleviate the contradiction between the labor supply and demand structures". Based on this, the modern apprenticeship has become a hot topic in the process of education and teaching reform in Higher Vocational Colleges in recent years.

\section{The problems in the implementation of the modern apprenticeship system}

The implementation of the modern apprenticeship training model has promoted the students' practical skills and professional qualities, and promoted and improved the employment of graduates in higher vocational colleges. At the same time, the implementation of the modern apprenticeship system of talent training mode makes it possible for higher vocational colleges to deliver more high-quality and highly skilled talents to the society, which is conducive to the improvement of the plight of "labor shortage". However, there are some problems to be solved in the implementation of the modern apprenticeship system. This paper analyzes the two aspects of the external environment and internal factors, and summarizes these problems into four aspects: the government, the enterprise, the school and the students.

\subsection{Government aspects}

At present, the relevant laws in vocational education can be based on 《the Law of Higher Education》 and 《the Law of Vocational Education》. In terms of modern apprenticeship and school enterprise cooperation, there is no special legislation or regulations to guarantee the interests of both schools and enterprises and to restrain the behavior of both schools and enterprises. However, in the process of implementing modern apprenticeship, there are many matters requiring detailed rules and legal documents. For example, stipulates the obligations that enterprises should perform in the process of implementing modern apprenticeship, and offers preferential policies to enterprises participating in apprenticeship. Without the guarantee of the relevant legal system, the enterprise 
side often lacks the motivation and sense of obligation to participate in the modern apprenticeship system. In addition, the process of modern apprenticeship implementation is a process of capital investment. Students enter the enterprise from the school. For the enterprise, the training cost is difficult to recover in a short time. If there is no special financial subsidy and preferential policy, it is difficult to arouse the enthusiasm of the enterprise to participate in the apprenticeship. In addition, in the process of the construction of modern apprenticeship, the innovation of talent training mode, the construction of the teachers' team, the improvement of the assessment methods and the improvement of the training conditions require funds to be started and maintained in many aspects. Once the education funds are short or lagged, it is very likely that the apprenticeship system will become a mere formality.

\subsection{Enterprise aspects}

A prominent phenomenon in the implementation of modern apprenticeship is "enterprise cooling, school craze". The enterprise is a profit-making organization that pursues profit and rate of return; and the school is a public welfare organization, taking education as its responsibility. The two subjects of completely different nature need to carry out the modern apprenticeship system together. There are many problems in the unity of goals and the interests of coordination, and most of these problems come from the enterprise. In the implementation of apprenticeship, many enterprises are lack of motivation. The implementation of the modern apprenticeship requires enterprises to send special technical backbone to guide and train them, while also taking on the wages of the students and the security problems during their work. The actual productivity of the students is often lower than the capacity requirements of the enterprise. Even after a period of training, the apprenticeship can be fully qualified for the job requirements, and there is no difference from the official job. But when the internship expires, they do not have to choose to be employed in the internship. This leads to the difficulty of reclaiming profits for enterprises in the short term. Besides, in the process of participating in apprenticeship, enterprises have too much freedom and lack effective constraints, so it is difficult to establish a long-term mechanism for apprenticeship in schools and enterprises. When the labor force is short, some enterprises actively participate in the apprenticeship system, only in order to obtain the short-term cheap labor force, and do not train talented people well. But when these enterprises have sufficient labor force, they will close the gate of school enterprise cooperation, which makes the modern apprenticeship system do not have the basic guarantee.

\subsection{School aspects}

Higher vocational colleges are the main organizers and leaders of the modern apprenticeship system. The success of the modern apprenticeship training mode depends partly on whether the efforts of the schools are in place. First of all, schools must work together with business experts to discuss and formulate curriculum standards to ensure that the curriculum standards meet the industry standards and the teaching content meets the needs of the post. However, some schools do not strictly carry out this point. Only on the basis of the original curriculum standards, they have made a simple adjustment against the job characteristics of the enterprise, and it lacks the effective participation and repeated argument of the enterprise experts. This makes students lack of targeted theoretical knowledge as support after entering the internship. Secondly, the modern apprenticeship teaching mode needs a team of teachers with double certificates, while many vocational colleges value academic qualifications and neglect skills, when they set up a teaching team. As for the engineering cost specialty, the teachers who lack practical experience often have little connection with the actual production, which is difficult to make good connection with the practice teaching of enterprise teachers. Thirdly, the examination and evaluation of the modern apprenticeship personnel training mode adopts the double standard, that is, the school and enterprise jointly formulate the examination content and standard, and strictly implement the method of combining the school assessment and the enterprise assessment. However, in practice, the school side has not been able to control the quality of enterprise assessment very well. Even if the school sends teachers to the enterprise, it will become a mere formality. The development of modern apprenticeship is not to send students to enterprises and ignore them, but to strengthen the cooperation and communication 
with enterprises more frequently.

\subsection{Student aspects}

Students are the biggest beneficiaries of modern apprenticeship training mode. The implementation of apprenticeship enables students to get good internship opportunities. The promotion of practical skills and post literacy can effectively promote students' employment and achieve zero distance job placement. However, in the implementation of modern apprenticeship, students' problems should not be underestimated. The problem of students is first manifested the lack of understanding of modern apprenticeship and improper attitude to practice. Some students do not understand the significance of the modern apprenticeship training model, mistaken that apprenticeship is the transaction between schools and enterprises, and students only act as cheap labor. Although the students can understand the meaning of modern apprenticeship, they do not have a correct attitude, just take the practice training as means to get credit and diploma, which is often difficult to harvest good practice effect. Besides, for most students who participate in apprenticeship, the most prominent problem is that it is difficult to adapt to the transformation of "dual identity ". The students must adapt to the living environment, adapt to the working atmosphere, adapt to the relationship between teachers and apprenticeship, and adapt to the group of colleagues, which are the challenges they need to face. We have to admit that there are still some students who have not been able to complete the transformation of "dual identity" well and deviate from the original intention of practicing the modern apprenticeship system.

\section{Measures to improve the modern apprenticeship system}

Through the analysis of the above, we know that the implementation of the modern apprenticeship system still has some aspects to be improved. In view of the existing problems of the modern apprenticeship, this paper puts forward the corresponding measures and suggestions from the four aspects of the government, the association, the school and the students.

\subsection{Government should further strengthen its support}

In the modern apprenticeship mode of school enterprise cooperation, enterprises often show a "cold" feature. This is because that enterprises as for-profit organizations, which in the process of the implementation of modern apprenticeship, do not feel the benefits of "lucrative", and the initial investment is difficult to recover profits, so its enthusiasm is low. Based on this, the government should increase the support for the apprenticeship from two aspects of legislation and finance. Firstly, the government can promulgate special laws and regulations to clearly stipulate the rights and obligations of both schools and enterprises in the construction of modern apprenticeship. At the same time, preferential policies should be given to enterprises that are actively involved in modern apprenticeship construction, and corresponding punishments should be given to those enterprises that are in negative conflict with the construction of modern apprenticeship. Secondly, by increasing the financial subsidy, the government will share the cost of the modern apprenticeship construction, so as to reduce the economic pressure of the enterprise. Thirdly, the government can also set up special funds to help the school side to train teachers and improve training places in the construction of modern apprenticeship.

\subsection{Industry associations fully play the role of coordination}

Taking engineering cost enterprises as an example, in a certain scope of administrative division (such as city), we can take the lead of several large cost companies to gather local cost enterprises and to form association organizations. The association organization represents the common interests of the local cost industry, and has the functions of organization, coordination, supervision and service function. In the process of promoting the construction of the apprenticeship system, the industry association should give full play to its coordination function and become the medium for the government and the university to contact the enterprise. At the same time, it can also express the demands of the enterprise to the government and the school to maintain the common interests of the 
enterprises in the industry. In addition, the industry association should also provide experts, serve as consultants for modern apprenticeship construction, who will fully participate in the formulation of curriculum standards and assessment standards, and fully participate in the identification of professional competence and the issue of qualification certificates. The emergence of industry associations can not only effectively safeguard the interests of enterprises, but also integrate the dispersed enterprises into an organic and orderly group, which is beneficial to the development and implementation of the modern apprenticeship system.

\subsection{Higher vocational colleges continue to improve self- construction of modern apprenticeship}

As the main body of the modern apprenticeship construction, the higher vocational colleges should give full play to their own leading role. Under the guidance of government and the coordination of the industry association,the process of the modern apprenticeship should be actively promoted by higher vocational colleges. The establishment of curriculum standards, teaching content and assessment system in higher vocational colleges should be discussed and repeatedly demonstrated with enterprises to ensure the adaptation of teaching standards to industry standards, the adaptation of teaching content to post requirements, and the adaptation of assessment system to professional qualifications. In addition, the higher vocational colleges should strengthen the construction of a teacher team with double certificates. On the basis of paying attention to the level of teachers' theory and teaching ability, higher vocational colleges should improve the practical operation skills of the teachers and encourage the teachers to participate in the training of the enterprises. In addition, higher vocational colleges should strictly control assessment mechanism and work together with enterprises to formulate assessment standards and implementation methods, especially to ensure that the assessment are strictly, truthful, fair and effective in the enterprise training stage. This requires the school side to do a good job in process supervision and quality control.

\subsection{Schools and enterprises assist students to adapt to their identity conversion}

Under the modern apprenticeship mode, the students need to enter the internship stage after completing the theoretical study inside the school. The transition from student to apprenticeship is a challenge for students themselves. This requires both sides of the school and the enterprise to care and help students complete their identity transformation. The school should be equipped with a special teacher as intern instructors. An internship instructor is responsible for guiding several intern students. At the same time, the intern instructor should strengthen the concern for students, and go to the enterprise regularly to understand the life and work of students and find out the problems in time. For the enterprise, the enterprise technicians who serve as "teacher" are in contact with the students most. The enterprise should strengthen the investigation of the professional skills and moral character of the "teachers" to ensure that the students can effectively improve the practical ability and establish a good and harmonious relationship between them. In addition, enterprises should cooperate with schools to arrange students' daily life during internship so as to ensure students' physical and mental health.

\section{Summary}

Taking the engineering cost specialty as an example, this paper studies the problems faced by the higher vocational colleges in the process of implementing the modern apprenticeship system, and deeply excavates the root of the problems. On this basis, the paper puts forward some suggestions for the development of modern apprenticeship from four levels: government, industry associations, universities and students. It provides a theoretical reference for higher vocational colleges to promote the construction of modern apprenticeship. 


\section{Acknowledgements}

Research and practice of training model of professional personnel in higher vocational engineering under modern apprenticeship (ZJXH2017202), Construction and development of engineering cost curriculum in higher vocational colleges based on apprenticeship system.

\section{References}

[1] Niu Yuqin. Research on the Dynamic Mechanism of Engineering Cost Professional Participation in Modern Apprenticeship System [J]. Residential and Real Estate, 2017(7): 38-39.

[2] Xu Guoqing. The Strategy of Developing Modern Apprenticeship in Higher Vocational Education: Based on the Analysis of Modernity [J]. Higher Vocational Education, 2017: 79-84.

[3] Gao Kuifen. Problems and Countermeasures in the Implementation of Modern Apprenticeship System in Higher Vocational Colleges__Based on the Thinking of the Modern Apprenticeship Teaching Exchange Seminar in Vocational Colleges[J].Journal of Henan University of Science and Technology,2014(6):5- 9 .

[4] Zhang Di. Research on Modern Apprenticeship in Architectural Majors in Higher Vocational Colleges [J]. Teaching and Research, 2013(1): 95-96.

[5] Zhang Qifu. Trial of Modern Apprenticeship in Higher Vocational Colleges: Dilemma and Practice Strategy [J]. Journal of Educational Development Research, 2015(3): 45-50.

[6] Jia Wensheng, Pan Jianfeng, Liang Ningsen. The System Bottleneck and Practice Exploration of Modern Apprenticeship Construction in Higher Vocational Colleges [J]. JOURNAL OF EAST CHINA NORMAL UNIVERSITY, 2017(1): 47-53.

[7] Li Xiang. Research on the Current Situation and Countermeasures of the Trial of Modern Apprenticeship System in Higher Vocational Colleges [J].Journal of Changzhou University (Social Science Edition), 2015(1):121-124.

[8] Li Bin. Research on the application of modern apprenticeship training methods in engineering cost specialty [J].Journal of Tianjin Vocational College, 2016(4):44-48.

[9] Wu Jianshe. Five Major Problems in the Implementation of Modern Apprenticeship in Higher Vocational Education [J]. Higher Education Research, 2014(7): 41-45. 